\title{
Factors Influencing the Development of Nairobi Securities Exchange
}

\author{
Dr. Fredrick M.Kalui \\ Department of Accounting, Finance and Management Science, \\ Egerton University, Njoro, Kenya \\ Lucy Kalekye Musya \\ Egerton University, Njoro, Kenya
}

Doi:10.19044/esj.2019.v15n4p308 ～$\underline{\text { URL:http://dx.doi.org/10.19044/esj.2019.v15n4p308 }}$

\begin{abstract}
This study aimed to find out the factors influencing the development of the Nairobi Securities Exchange. The general objective of this study was to determine the factors that affect the development of the NSE. The specific objectives were to determine the effect of market information; market efficiency; market transparency; market openness; transaction processing system and operating/transaction cost; legal and regulatory framework on the development of the NSE. Both primary and secondary data collection methods were used. A semi- structured data collection questionnaire was used to collect primary data on institutional factors while secondary data was collected on market capitalization from 2006 to 2015 which was used as the indicator of NSE development. The study employed a descriptive research design to describe the empirical data. The population of study was all licensed stock brokers in the Nairobi Securities Exchange. A regression model was used for data analysis and hypothesis tested with a 0.05 significance level. This study concludes that market information, market efficiency, market openness, market transparency, transaction processing system and transaction/operating cost and legal and regulatory framework affects the development of Nairobi securities Exchange.The study recommends that developing countries to initiate policies to foster growth and development as countries liberalize their financial systems and further enhance domestic resource mobilization.
\end{abstract}

Keywords: Factors Affecting, Market Development,NSE

\subsection{Introduction}

The financial market handles the exchange of assets and is made up by several separate markets for various types of asset classes. Capital markets provide trading services for long-term securities such as shares and bonds with 
a maturity of more than one year. Other markets include money markets for shorter-term bonds; currency markets for foreign exchange; commodities markets where anything from metals to grain is traded; mortgage markets for property debt; and derivatives markets with products based on the underlying assets of all previously mentioned markets and more. (Saunders, 2004)

Emerging capital markets are financial markets that reside in the low or middle income economies or where the ratio of investable market capitalization to group to Gross National Product is low. Such parameters to classify the financial market are set by international finance corporation. Generally, there is no definition of emerging capital market. The international Finance corporation (IFC) defines an emerging market as one in which is found in developing country (IFC, 1994). According to Emerging Economies Report, The Centre for knowledge Societies give examples of emerging markets as India, China, Indonesia, South Africa, Kenya, Egypt and Brazil (Joshi et al. 2008). .

The development of African stock exchanges is growing in importance because of the important role they play in facilitating higher savings rate of the working population, offering of variety of securities to as many people as possible, flow of foreign direct investment into long established or recently introduced companies distribution on capital in the most productive sectors of the economy redistribution of wealth in the economy and improved corporate governance through increased transparency. In most emerging economies, the capital market has not yet played its role in capital mobilization, though if properly organized it could be a source of the much needed capital necessary for economic growth (Chepkoiwo, 2011)

Stock exchanges are a modern focal point for raising cheap long term capital and for the mobilization of savings. They also help increase transparency in the privatization process by encouraging wider share ownership. Stock exchanges improve efficiency in resource allocation through a competitive mechanism. They increase liquidity and provide risk capital for trail blazing ventures (Wang and Ang, 2004). They help release idle funds for investment because they generally provide higher rates of return than alternative investments. When successful, activity in the market provides a strong impetus for economic growth (Wagacha, 2000b). Despite these advantages, the growth of the stock exchange in Kenya has been relatively slow, and has especially received a poor response from private companies wishing to raise capital.

The proponents of stock markets emphasize the importance of having a developed stock market in enhancing the efficiency of investment. A wellfunctioning stock market is expected to lead to a lower cost of equity capital for firms and allow individuals to more effectively price and hedge risk. Stock markets can attract foreign portfolio capital and increase domestic resource 
mobilization, expanding the resources available for investment in developing countries. Recognizing the importance of stock market on economic growth, prudential authorities such as World Bank, IMF and ADB undertook stock market development programs for emerging markets in developing countries during 80s and 90s and they found that, emerging stock markets have experienced considerable development since the early 1990s. (Yartey, 2008).

Kenya's capital market has come a long way since the country's independence in 1963. The capital market now comprise of; the trading debt and equity over the Nairobi Stock Exchange(NSE); debt capital markets(bonds); development financial institutions (DFI's) and pension funds. The financial sector plays a crucial role in financial sector development and the realization of value. In particular, the market assists in price discovery, liquidity provision and proper allocation of risk between various participants on a more macro-economic level, the capital market is positively correlated to a country's economic growth (Chepkoiwo, 2011).

\subsection{Statement of the Problem}

The securities market is an essential market playing a vital role in economic prosperity hence fostering capital formation and sustaining economic growth as they facilitate the flow of resources to the most productive investment opportunities in other words; they help in terms of efficient allocation of credit in the economy. They are more than a place to trade securities; they operate as a facilitator between savers and users of capital by means of pooling of funds, sharing risk, and transferring wealth. The benefits of well-developed and dynamic markets are numerous; they increase the level and sophistication of financial intermediation in an economy while offering to the investing public a variety of financial products and promote economic growth through increased access to savings and risk diversification, cause economic growth and has positive impact on poverty alleviation and income distribution as well (Sejjaaka, 2011).

The government of Kenya, in realizing the importance of the securities market, instituted various measures including automation, removal of capital gains tax and establishment of a regulatory body called Capital Market Authority (CMA) in the late 1980s, despite all these apparent benefits and measures instituted by the government at different times, performance indicators show that the NSE hasn't yet performed to its full potential compared to other securities markets. These include: low turnover ratio, low market capitalization to GDP ratio and low value of stock (Angko, 2013)

Most studies on the development of Nairobi Securities Exchange including Chepkoiwo (2011), Aduda et al (2012), have often focused on the macroeconomic factors and no study has devoted much attention to market infrastructure factors. The need for a quicker development of a well-organized 
and functioning capital market has become extremely important, and in light of this knowledge gap, a better understanding of the factors affecting the development of Nairobi Securities Exchange was of vital importance.

\subsection{Objective of the Study}

\subsubsection{General Objective of the study}

The general objective of the study was to determine the factors that affect the development of Nairobi Securities Exchange.

\subsubsection{Specific Objectives of the Study}

i. To determine the effect of market information and on the development of Nairobi Securities Exchange.

ii. To determine the effect of market efficiency on the development of Nairobi Securities Exchange.

iii. To determine the effect of market transparency on the development of Nairobi Securities Exchange.

iv. To determine the effect of market openness on the development of Nairobi Securities Exchange.

v. To determine the effect of transaction processing system and operating/ transaction cost on the development of Nairobi Securities Exchange.

vi. To determine the effect of legal and regulatory framework on the development of Nairobi Securities Exchange.

\subsection{Research Hypothesis}

Ho1-Market information does not significantly affect the development of Nairobi Securities Exchange.

$\mathbf{H}_{\text {O2 }}$-Market efficiency does not significantly affect the development of Nairobi Securities Exchange.

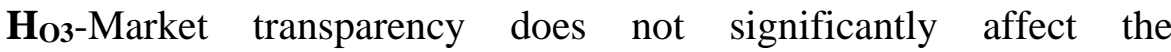
development of Nairobi Securities Exchange.

Ho4-Market openness does not significantly affect the development of Nairobi Securities Exchange.

Hos- Transaction processing system and operating/ transaction cost does not significantly affect the development of Nairobi Securities Exchange.

Ho6-Legal and regulatory framework does not significantly affect the development of Nairobi Securities Exchange. 


\section{Literature Review}

\section{The Efficient Market Hypothesis-}

Capital market development is an important component of financial sector development and supplements the role of the banking systems in economic development. Specifically, capital markets assist in price discovery, liquidity provision, reduction in transaction costs and risk transfer. They reduce information cost through generation and dissemination of information on firms leading to efficient markets in which prices incorporate all available information (Yartey and Adjasi (2007),

The Efficient Market Hypothesis (EMH) is a theory developed by Eugene Fama which states that stocks always trade at their fair value, making it impossible for investors to either purchase undervalued stocks or sell stocks for inflated prices; as such asset prices fully reflect all available information. Since stocks always trade at their fair value, it is impossible for investors to outperform the overall market through expert stock selection or market timing, and that the only way an investor can possibly obtain higher returns is by chance or by purchasing riskier investments.

There are three variant forms of market efficiency; weak, semi-strong and strong. Weak EMH states that prices on traded assets reflect all past publicly available information. In a Semi-Strong EMH prices reflect all publicly available information and that prices instantly reflect new public information. Strong EMH states that prices instantly reflect every hidden information (Burton, 1996). According to the EMH therefore all stocks are perfectly priced and all market participants possess this knowledge equally. This theory is important to this study since the confidence investors have on the efficiency of the market may have an effect on them investing in it and thus its development.

\section{The Behavioural Theory}

The efficient Market theory concept was later challenged by academicians although there is sufficient evidence of the relevance of the theory. Academicians and other practitioners recognize that emotions and other subjective factors play a role in investment decisions which has resulted in a significant research which is referred to as behavioral finance (Gitman, 2006). Behavioral finance hold the view that, in practice, markets are far from perfect and investors are not rational but are motivated by greed, fear and other emotions.

According to the behavioralists, many investors let their emotions overrule rational analysis. They say even the most rational investor cannot totally eliminate emotion. Emotion is an important aspect of human condition can influence decision making (Gitman, 2006). The emotional state of 
investors was no doubt the most important factors causing historical market dip in the NSE during the post election violence in 2008.

\section{The Nairobi Securities Exchange (NSE)}

The Nairobi Securities Exchange was established in the 1920's by the British as an informal market for Europeans only. In 1954, the market was formalized through incorporation into a company. The NSE was registered under the Companies Act in 1991 and phased out the "call over" trading system in favour of the floor- based "open Outcry System". Subsequently the stock exchange embarked on an extensive modernization exercise, including a move to more spacious premises at the Nation Centre in July 1994.

The facilities included a modern information centre. The improvement of market infrastructure through the development of an automated central clearing settlement and depository system (CDS) intended to serve the East African region. With the incorporation of the central Depository \& settlement corporation, share trading became electronic via the Central Depository System. This contributed to increased turnover. The Electronic Trading System (ETS) recently implemented (2007) is also expected to increase turnover and efficiency at the bourse (The NSE Market Fact File 2016).

\section{Factors Affecting the Development of Securities Exchange Legal and Regulatory Infrastructure}

The regulatory infrastructure relates not only to the government body that has the power and responsibility to supervise the market, but also includes self-regulatory organizations such as stock exchanges, accounting standards boards, and accounting and auditing professional associations and similar organizations. It also includes their rules and regulations, procedures, and facilities such as stock exchange listing and trading rules or accounting and auditing standards, plus the monitoring and enforcement of these rules.

Currently, there are multiplicity of regulators and regulations in Kenya governing the capital market. They include the Central Bank of Kenya, Capital Markets Authority, Retirement Benefits Authority and Commissioner of Insurance. All these bodies enact policies that affect the development of the stock Market. The Capital Markets Authority as the regulatory agency must alter its approach from the sometimes heavy-handed type of control to a more proactive, creative and supportive role in order to assist in the creation of a more vibrant and forward looking capital market environment by seeing itself as a catalyst in development rather than as a traditional regulator of what is a very small market (Capital Markets Authority, 2016). 


\section{Market Infrastructure and Institutional Factors}

The market infrastructure should be capable of supporting efficient operation of the securities market. i.e., the securities market should operate in an efficient, fair and stable manner. Market infrastructure factors were the independent variable for this study.

The institutional infrastructure provides the operational basis for the market. It relates to intermediaries that provide trading, investment management and financial advisory services; market and market-related service providers for stock exchanges, over-the-counter markets, market information services, transaction clearance and settlement systems, and securities transfer, registration and custody; and providers of ancillary services such as accounting and auditing, legal advice, and financial valuation and debt rating services.

\section{Market Information and Efficiency}

Kimura and Amoro, (1999) argue that the major factor contributing to poor performance of the NSE is general lack of awareness and information on the role, functions and operations of the stock exchange. For companies, the question is not so much lack of knowledge but a concern that the risks associated with additional disclosure are not adequately compensated by additional returns. Public disclosure of relevant information about securities is important for both pricing efficiency and market confidence

\section{Market Transparency}

Analyzing the amount of information available in the emerging markets raises the notion of the accuracy of the information. The degree to which markets are transparent and competitive affect investors' ability to gain information and develop performance expectations. Though all markets exhibit varying degrees of transparency, emerging markets are likely to be less transparent than developed market.

Transparency of trading and other procedures allows efficient price setting and confidence in the fairness of the market. Fragmented or privately conducted trading with limited disclosure of quantity and price means that each new transaction in effect must be based on relatively expensive search costs and there is a risk of the transaction going out of line with prevailing prices. Opaque trading procedures engender suspicion of market manipulation and may reduce the rate of investment (Osei, 1998)

\section{Market Openness}

Market can be open or closed to foreign investors. Excessive barriers especially to foreign investors hamper the development of any stock exchange. Example is the Kenyan $25 \%$ rule where investors are to allow the locals to 
own 25\% of holding in any foreign investment in Kenya. Bruner et al (2003) studied 33 developing countries to ascertain the extend of market openness in those countries. However, they noted that only 18 out of 33 listed as emerging markets are 100\% open to foreign investment and the remaining 15 markets are either closed to foreign investment or having varying restrictions on foreign ownership.

The most common restriction includes; special classes of shares for foreign owners; limits on foreign ownership; limits on ownership held by a single foreign shareholder; company imposed limits that differ from national law; and national limits on aggregate foreign ownership. Demirgug \& Levine (1996) finds that he restriction placed on foreign investors on the above restrictions constrain the performance of the capital market. However, the restrictions vary from one country to the other.

\section{Transaction Processing System and Transaction Cost}

The transaction clearance and settlement systems, securities transfer, registration and custody contributes to the development of the stock market. This challenge was being addressed in Kenya with the introduction of the central depository system (CDS)

The operating-transaction costs should be within acceptable limits aimed at minimizing costs in order to maximize returns. Unreasonably high costs of transactions will affect market development since investors aim at minimizing cost to increase their returns. For companies going public through share issue and subsequently seeking listing on the exchange, the main costs are: underwriting fee, legal and accounting expenses, brokerage commissions, cost of printing and advertising prospectus and fees for the NSE. The cost of going public as percentage of capital raised decreases as more capital is raised. It is also cheaper to raise capital through private placement than through public issue. (Osei, 1998)

For individuals buying and selling shares on the stock exchange, the main cost is brokerage commissions. A latent cost is the interest forgone when payment is made to the broker while the investor waits, sometimes for a couple of weeks or more, before the stock is purchased. (Osei, 1998).

\section{Research Methodology and Results Research Design}

The main reason for the use of a descriptive survey design is the aim to provide as much information on the entire population under study in relation to market infrastructure factors affecting the development of NSE. It was relevant for this study as raw data was used as collected from stock brokers. Survey designs are of particular value to researchers seeking help on investigating and analysis interrelationships of a number of factors involved, 
and in which it is difficult to understand the individual factors without considering their relationships with each other Mugenda\&Mugenda, (1999).

\section{Target Population}

In studying the NSE, the study population was brokerage firms licensed by the capital market authority. There are currently 23 licensed stock brokers with two of them placed under statutory management. The researcher carried out a census on all the 21 licensed firms (other than those placed under statutory management). For each brokerage firm, respondents were the investment and risk managers. The study utilized both primary and secondary data to find out the factors that affect the development of the NSE. Selfadministered semi-structured questionnaire consisting of closed-ended questions were designed, and administered at one point and given to the respondents from the brokerage firms targeting two questionnaires per brokerage firm. For the purpose of this study, the secondary data was obtained for a period of 10 years, spanning between years $2006-2015$. The researcher obtained data to study the dependent variable which is market capitalization ratio from the NSE, Central Bank of Kenya and International Monetary Fund IMF website (Kenyan GPD per capita) and KIPPRA.

\section{Data Analysis}

Since both primary and secondary data were used, descriptive statistics analysis was used. Descriptive statistics describe data on variables with single numbers while analysis of variance (ANOVA) tests for any significance difference between mean values of variables. Arithmetic mean, median, maximum, minimum and the standard deviation are some of the main descriptive statistics that were applied in data analysis.

The study used a multiple regression model to test the the hypotheses of the combined effect of the six independent variables on the dependent variable. The hypothesis was tested on a 0.05 significance level. Studies by Yartey (2008) and Lazaridis and Trofornidis (2006) have used regression analysis while studying relationships among variables. The regression model below was used to determine the impact of each variable in the development of the NSE.

\section{$\mathbf{y}=\beta 0+\beta_{1} X_{1}+\beta_{2} X_{2}+\beta_{3} X_{3}+\beta_{4} X_{4}+\beta_{5} X_{5}+\beta_{6} X_{6}+e$ \\ Where:}

$\mathrm{y}=$ Market Capitalization Ratio, $\beta 0=$ Constant Term, $\beta \mathrm{i}=$ Beta coefficients, X1= Market Information, X2= Market Efficiency, X3= Market Transparency, $\mathrm{X} 4=$ Market Openness

X5= Transaction Processing System and Operating/ Transaction Cost, X6= Legal and Regulatory Framework, e=Standard error. 
The independent variables were measured using a 5 point likert scale in a questionnaire ranging from strongly disagree(1), disagree(2), neutral(3), agree (4) to strongly disagree(5). To enable analysis and clarity of the information sourced; the Likert scale values used on the questionnaire were converted into percentages with equal interval assumption (Trochim, 2006).

Table 1: Operationalization of Variables

\begin{tabular}{|l|l|l|}
\hline Variable & Indicator/Proxy & Measure \\
\hline Market information & Extent of information disclosure & 5 point likert scale \\
\hline Market efficiency & $\begin{array}{l}\text { Ability of Prices to reflect all } \\
\text { information }\end{array}$ & 5 point likert scale \\
\hline Market transparency & Disclosure of all transactions & 5 point likert scale \\
\hline Market openness & $\begin{array}{l}\text { Restriction on shares ownership/ } \\
\text { free exit/entry }\end{array}$ & 5 point likert scale \\
\hline $\begin{array}{l}\text { Transaction processing } \\
\text { system }\end{array}$ & Efficiency/effectiveness of CDS & 5 point likert scale \\
\hline $\begin{array}{l}\text { Legal \& regulatory } \\
\text { framework }\end{array}$ & Effectiveness of the regulations & 5 point likert scale \\
\hline $\begin{array}{l}\text { Market capitalization } \\
\text { proportion of GDP }\end{array}$ & $\begin{array}{l}\text { value of listed shares } \\
\text { divided by GDP }\end{array}$ \\
\hline
\end{tabular}

\section{Results and Discussion}

\section{Validity and Reliability of Test Results}

Content validity of the adopted research instruments was assessed by seeking expert opinion to ascertain the consistency of the questionnaire. The pilot study tested the clarity of instructions, relevance, terminology used and comprehensibility. It also identified ambiguity and any other issues that may have arisen and replaced such questions with focused one.

Reliability is an indication of the stability and consistency with which the instrument measures a concept and helps to assess the goodness of the measure. In this study, Cornbrash'salpha, which is a reliability coefficient, was used to indicate how well the items in the study were correlated with each other. The reliability results obtained are shown below:

Table 2

\begin{tabular}{|c|r|r|c|}
\hline Variable & Cornbrash's alpha & Number of items & Comment \\
Market information & 0.782 & 6 & Accepted \\
Market efficiency & 0.797 & 6 & Accepted \\
Market transparency & 0.86 & 6 & Accepted \\
Market openness & 0.718 & 6 & Accepted \\
TPS \& Operating/ transaction cost & 0.754 & 6 & Accepted \\
Legal and regulatory framework & 0.769 & 6 & Accepted \\
\hline
\end{tabular}

Source: Research Data 2016

The reliability results indicate that all the variables had a Cronbach's alpha above the acceptable minimum coefficient of 0.7 and good internal 
consistency. On average, a Cronbach's alpha of 0.780 was found indicating acceptable reliability of the data. Based on this therefore, all items were accepted and considered for the study

\section{Market Information}

The result of the study indicated that market information affects the development of Nairobi Securities Exchange by 3.8 or $76 \% .86 \%$ agreed that unsuspecting investors can be harmed by those with access to information not available to the public at large with $80 \%$ agreeing that the managers of a firm and financial market professionals know more about that firm's market prospects and investment opportunities than do outsiders as they often have access to information that is not widely available. $66 \%$ of the respondents agreed that investor access to information pertaining to their prospective investments is more limited than that of professional intermediaries and $88 \%$ were of the opinion that disclosure will facilitate increased investors' confidence in the stock markets.

Respondents agree that listed companies trading in NSE are subjected to additional disclosure requirements imposed as listing rules with an agreement rate of $88 \%$. The study also revealed that information asymmetries are the basic justification for the large number of regulations at the NSE at $72 \%$ and the respondents agreed that there are still some barriers to the dissemination of information in the NSE at 58\% agreement rate. The overall response was as shown in the figure below;

Table 3: Market Information Effect on Development of NSE

\begin{tabular}{|c|c|c|c|c|c|c|c|c|}
\hline \multirow[b]{2}{*}{ Market Information } & \multirow[b]{2}{*}{ SD } & \multicolumn{7}{|c|}{ PERCENTAGES } \\
\hline & & D & $\mathbf{N}$ & A & SA & $\begin{array}{c}\text { Mea } \\
\text { n }\end{array}$ & $\begin{array}{c}\text { Mean } \\
(\%)\end{array}$ & $\begin{array}{l}\text { STD } \\
\text { DEV }\end{array}$ \\
\hline Unsuspecting Investors Can be Harmed & 0 & 5.9 & 2.9 & 44.1 & 47.1 & 4.3 & 86 & 0.8061 \\
\hline Managers Know More of Financial Market & 2.9 & 5.9 & 14.7 & 44.1 & 32.4 & 4 & 80 & 0.9996 \\
\hline Financial Market & 9.1 & 3 & 30.3 & 39.4 & 18.2 & 3.5 & 70 & 1.1206 \\
\hline $\begin{array}{l}\text { Investor Access to information pertaining to } \\
\text { their prospective investments is more limited } \\
\text { than that of professional intermediaries }\end{array}$ & 5.9 & 17.6 & 29.4 & 35.3 & 11.8 & 3.3 & 66 & 1.0879 \\
\hline $\begin{array}{l}\text { Disclosure will facilitate increased investors' } \\
\text { confidence in the stock markets }\end{array}$ & 0 & 0 & 11.8 & 38.2 & 50 & 4.4 & 88 & 0.697 \\
\hline $\begin{array}{l}\text { Listed companies trading in NSE are } \\
\text { subjected to additional disclosure } \\
\text { requirements imposed as listing rules } \\
\end{array}$ & 0 & 0 & 11.8 & 38.2 & 50 & 4.4 & 88 & 0.697 \\
\hline $\begin{array}{c}\text { Information asymmetries are the basic } \\
\text { justification for the large number of } \\
\text { regulations at the NSE }\end{array}$ & 2.9 & 5.9 & 29.4 & 47.1 & 14.7 & 3.6 & 72 & 0.9173 \\
\hline $\begin{array}{c}\text { There are many barriers to the dissemination } \\
\text { of information in the NSE }\end{array}$ & 18 & 23.5 & 24 & 26.5 & 8.8 & 2.9 & 58 & 1.2585 \\
\hline & & & & & & 3.8 & 76 & 0.948 \\
\hline
\end{tabular}




\section{Market Efficiency}

The result of the study indicated that market efficiency affects the development of Nairobi Securities Exchange by $67.8 \%$. According to the study, $54.7 \%$ agreed that prices of securities listed at the NSE do not reflect all available information but only some and $88.2 \%$ of the respondents agreed that public disclosure of relevant information about securities is important for pricing efficiency and market confidence. The results of the study indicate a $69.4 \%$ agreement that there are some information asymmetries in the NSE with $58.8 \%$ under-pricing of securities by investment banks in Kenya. The overall response was as shown in the figure below;

Table 4: Market Efficiency Effect on Development of NSE

\begin{tabular}{|c|c|c|c|c|c|c|c|c|}
\hline \multirow[b]{2}{*}{ Market efficiency } & \multirow[b]{2}{*}{ SD } & \multicolumn{7}{|c|}{ PERCENTAGES } \\
\hline & & D & $\mathbf{N}$ & $\mathbf{A}$ & $\mathbf{S A}$ & Mean & $\begin{array}{c}\text { Mean } \\
(\%)\end{array}$ & $\begin{array}{l}\text { STD } \\
\text { DEV }\end{array}$ \\
\hline $\begin{array}{c}\text { Prices of securities listed at the } \\
\text { NSE reflect all available } \\
\text { information }\end{array}$ & 14.7 & 26.5 & 35.3 & 17.6 & 5.9 & 2.7 & 54.7 & 1.1094 \\
\hline $\begin{array}{l}\text { Public disclosure of relevant } \\
\text { information about securities is } \\
\text { important for pricing efficiency } \\
\text { and market confidence. }\end{array}$ & 0 & 2.9 & 2.9 & 44.1 & 50 & 4.4 & 88.2 & 0.7014 \\
\hline $\begin{array}{c}\text { There are information } \\
\text { asymmetries in the NSE }\end{array}$ & 3 & 17.6 & 18 & 53 & 8.8 & 3.5 & 69.4 & 0.9919 \\
\hline $\begin{array}{l}\text { There is underpricing of securities } \\
\text { by investment banks in Kenya }\end{array}$ & 11.8 & 26.5 & 29.4 & 20.5 & 11.8 & 2.9 & 58.8 & 1.2046 \\
\hline & & & & & & 3.4 & 67.8 & 1.0 \\
\hline
\end{tabular}

Source: Research Data 2018

\section{Market Transparency}

The result of the study indicated that market transparency affects the development of Nairobi Securities Exchange by $75.9 \%$. According to the study, $67.6 \%$ of transactions are not made known to the public as $60.7 \%$ of trading is conducted privately outside the NSE. $84.7 \%$ of respondents agreed that emerging markets are likely to be less transparent than developed market. The degree of market transparency and competitive was said to affect by $85.9 \%$ the investors' ability to gain information and develop performance expectations since transparency in dealings enhance the market confidence by $89.4 \%$.

The study also supported at $74.1 \%$ the argument that fragmented or privately conducted trading with limited disclosure leads to relatively expensive search costs and there is a risk of the transaction going out of line with prevailing prices and that Transparency of trading and other procedures allows efficient price setting and confidence in the fairness of the market by $84.2 \%$. 
The study results reveal that opaque trading procedures engender suspicion of market manipulation and may reduce the rate of investment by 77.1\%. Respondents also agree that dealings done through brokers can enhance limited disclosure of some vital information and that $60 \%$ of market intermediaries in Kenya lead to market manipulation. The overall response was as shown in the figure below;

Table 5: Market Transparency Effect on Development of NSE

\begin{tabular}{|c|c|c|c|c|c|c|c|c|}
\hline \multirow[b]{2}{*}{ Market transparency } & \multirow[b]{2}{*}{ SD } & \multicolumn{7}{|c|}{ PERCENTAGES } \\
\hline & & D & $\mathbf{N}$ & A & SA & Mean & $\begin{array}{c}\text { Mean } \\
(\%)\end{array}$ & $\begin{array}{l}\text { STD } \\
\text { DEV }\end{array}$ \\
\hline $\begin{array}{l}\text { Every transaction isn't made known } \\
\text { to the public at the NSE }\end{array}$ & 14.7 & 14.7 & 14.7 & 29.4 & 26.5 & 3.4 & 67.6 & 1.4145 \\
\hline $\begin{array}{l}\text { Some trading is conducted privately } \\
\text { outside the NSE }\end{array}$ & 14.7 & 17.6 & 26.5 & 35.3 & 5.9 & 3.0 & 60.0 & 1.1807 \\
\hline $\begin{array}{c}\text { Emerging markets are less } \\
\text { transparent than developed market. }\end{array}$ & 0 & 5.9 & 8.8 & 41.2 & 44.1 & 4.2 & 84.7 & 0.8549 \\
\hline $\begin{array}{l}\text { Transparency in dealings enhance } \\
\text { the market confidence }\end{array}$ & 0 & 2.9 & 8.8 & 26.5 & 61.8 & 4.5 & 89.4 & 0.7876 \\
\hline $\begin{array}{l}\text { The degree of market transparency } \\
\text { affects investors' ability to gain } \\
\text { information and develop } \\
\text { performance expectations. }\end{array}$ & 0 & 0 & 14.7 & 41.2 & 44.1 & 4.3 & 85.9 & 0.719 \\
\hline $\begin{array}{l}\text { Transparency of trading and other } \\
\text { procedures allows efficient price } \\
\text { setting and confidence in the fairness } \\
\text { of the market. }\end{array}$ & 0 & 3 & 15.2 & 39.4 & 42.4 & 4.2 & 84.2 & 0.82 \\
\hline $\begin{array}{l}\text { Fragmented or privately conducted } \\
\text { trading with limited disclosure leads } \\
\text { to relatively expensive search costs } \\
\text { and there is a risk of the transaction } \\
\text { going out of line with prevailing } \\
\text { prices. }\end{array}$ & 5.9 & 8.8 & 14.7 & 50 & 20.6 & 3.7 & 74.1 & 1.0879 \\
\hline $\begin{array}{l}\text { Market intermediaries in Kenya } \\
\text { cause market manipulation. }\end{array}$ & 18 & 14.7 & 32 & 20.6 & 14.7 & 3.0 & 60.0 & 1.3027 \\
\hline $\begin{array}{l}\text { Opaque trading procedures engender } \\
\text { suspicion of market manipulation } \\
\text { and may reduce the rate of } \\
\text { investment. }\end{array}$ & 0 & 5.9 & 26.5 & 44.1 & 23.5 & 3.9 & 77.1 & 0.8575 \\
\hline & & & & & & 3.8 & 75.9 & 1.0 \\
\hline
\end{tabular}

Source: Research Data 2018

\section{Market Openness}

The result of the study indicated that market openness affects the development of Nairobi Securities Exchange by 59.6\%. According to the study, $32.1 \%$ of NSE is not open to all investors, local and foreign and respondents agreed at $58.8 \%$ that there are restrictions on foreign ownership at the NSE. Respondents agreed that excessive barriers to foreign investors at 
$69.4 \%$ including the $68.1 \%$ of the Kenyan $25 \%$ rule, hamper the development

of NSE. The overall response was as shown in the figure below;

Table 6: Market Openness Effect on Development of NSE

\begin{tabular}{|c|c|c|c|c|c|c|c|c|}
\hline \multirow[b]{2}{*}{ Market openness } & \multirow[b]{2}{*}{ SD } & \multicolumn{7}{|c|}{ PERCENTAGES } \\
\hline & & D & $\mathbf{N}$ & A & SA & Mean & $\begin{array}{c}\text { Mean } \\
(\%)\end{array}$ & $\begin{array}{l}\text { STD } \\
\text { DEV }\end{array}$ \\
\hline $\begin{array}{l}\text { NSE is not open to all investors, local } \\
\text { and foreign }\end{array}$ & 69.7 & 12.1 & 9.1 & 6.1 & 3 & 1.6 & 32.1 & 1.088 \\
\hline $\begin{array}{c}\text { There are restrictions on foreign } \\
\text { ownership at the NSE }\end{array}$ & 27.2 & 15.2 & 6.1 & 39.4 & 12.1 & 2.9 & 58.8 & 1.4778 \\
\hline $\begin{array}{c}\text { Excessive barriers to foreign investors } \\
\text { hamper the development of NSE }\end{array}$ & 11.8 & 11.8 & 15 & 41.2 & 20.5 & 3.5 & 69.4 & 1.2848 \\
\hline $\begin{array}{l}\text { Restrictions on foreign investors } \\
\text { constrain the performance of the capital } \\
\text { market. }\end{array}$ & 11.8 & 5.9 & 29.4 & 29.4 & 23.5 & 3.5 & 69.4 & 1.261 \\
\hline $\begin{array}{l}\text { The Kenyan } 25 \% \text { rule affects the } \\
\text { development of the NSE }\end{array}$ & 9.4 & 15.6 & 21.9 & 31.2 & 21.9 & 3.4 & 68.1 & 1.2664 \\
\hline & & & & & & 3.0 & 59.6 & 1.3 \\
\hline
\end{tabular}

Source: Research Data 2018

\section{Transaction Processing System and Operating/Transaction Cost}

The result of the study indicated that transaction processing system and operating/transaction cost affects the development of Nairobi Securities Exchange by $68.6 \%$. The results indicated that the clearance and settlement system used at the NSE is fast and effective at $59.4 \%$, with $41.2 \%$ of transactions being processed on time and this has led to increased turnover at the NSE. The processing system guarantee that the prices obtained by buyers and sellers are $63.5 \%$ good. $90 \%$ of investors' usually aim at minimizing cost to increase their returns and thus unreasonably high costs of transactions affect market development by $77 \%$. It is $68.2 \%$ cheaper to raise capital through private placement than through public issue though the cost of going public as percentage of capital raised decreases as more capital is raised by $78.2 \%$. Respondents agreed that for individuals buying and selling shares on the stock exchange, the main cost is brokerage commissions. The overall response was as shown in the figure below; 
Table 7: Transaction Processing System and Operating/Transaction Effect on Development of NSE

\begin{tabular}{|c|c|c|c|c|c|c|c|c|}
\hline $\begin{array}{c}\text { Transaction processing system } \\
\text { and Operating/transaction } \\
\text { cost }\end{array}$ & SD & D & $\mathbf{N}$ & $\mathbf{A}$ & SA & Mean & $\begin{array}{l}\text { CENT } \\
\text { Mean } \\
(\%)\end{array}$ & $\begin{array}{l}\text { SES } \\
\text { STD } \\
\text { DEV }\end{array}$ \\
\hline $\begin{array}{l}\text { Transactions take too long to be } \\
\text { processed at the NSE }\end{array}$ & 14.7 & 20.6 & 26.5 & 32.4 & 5.9 & 2.9 & 58.8 & 1.1791 \\
\hline $\begin{array}{c}\text { The CDS at the NSE is } \\
\text { ineffective }\end{array}$ & 32.4 & 38.2 & 23.5 & 5.9 & 0 & 2.0 & 40.6 & 0.904 \\
\hline $\begin{array}{l}\text { The processing system affects } \\
\text { the prices obtained by buyers } \\
\text { and sellers }\end{array}$ & 5.9 & 29.4 & 17.6 & 35.3 & 11.8 & 3.2 & 63.5 & 1.167 \\
\hline $\begin{array}{l}\text { Lengthy transactions affect the } \\
\text { turnover of the market }\end{array}$ & 2.9 & 14.7 & 20.6 & 41.2 & 20.6 & 3.6 & 72.4 & 1.0735 \\
\hline $\begin{array}{l}\text { Investors aim at minimizing } \\
\text { cost to increase their returns }\end{array}$ & 0 & 2.9 & 0 & 41.2 & 55.9 & 4.5 & 90.0 & 0.6629 \\
\hline $\begin{array}{c}\text { Unreasonably high costs of } \\
\text { transactions affect market } \\
\text { development }\end{array}$ & 6.1 & 9.1 & 18.2 & 27.3 & 39.4 & 3.8 & 77.0 & 1.2278 \\
\hline $\begin{array}{l}\text { The cost of going public as } \\
\text { percentage of capital raised } \\
\text { decreases as more capital is } \\
\text { raised. }\end{array}$ & 0 & 9.1 & 27.3 & 27.3 & 36.4 & 3.9 & 78.2 & 1.1011 \\
\hline $\begin{array}{l}\text { It is cheaper to raise capital } \\
\text { through private placement than } \\
\text { through public issue. }\end{array}$ & 11.8 & 11.8 & 20.6 & 35.3 & 20.6 & 3.4 & 68.2 & 1.282 \\
\hline & & & & & & 3.4 & 68.6 & 1.1 \\
\hline
\end{tabular}

Source: Research Data 2018

\section{Legal and Regulatory Framework}

The study indicated that legal and regulatory environment plays an important role in the development of the securities markets and affects the development of the NSE by $73.8 \% .58 .2 \%$ of respondents believe that legal and regulatory framework could be an impediment to NSE development thus favourable legal environment facilitates stock market development by $81.8 \%$ hence the law and enforcement mechanisms that protect creditors and minority investors the NSE.

The study indicated that laws and regulations at the NSE are 56.5\% prohibitive in nature. Regulatory bodies enact policies that affect the development of the stock Market by $75.9 \%$ but $60 \%$ of the times use a heavyhanded type of control. $80 \%$ of study results indicate that CMA is a catalyst in development rather than a traditional regulator of NSE with $84.7 \%$ agreeing that proactive, creative and supportive regulations assist in the creation of a more vibrant and forward looking capital market environment. The overall response was as shown in the figure below; 
Table 8: Legal and Regulatory Framework Effect on Development of NSE

\begin{tabular}{|c|c|c|c|c|c|c|c|c|}
\hline Legal and regulatory framework & SD & D & $\mathbf{N}$ & $\mathbf{A}$ & SA & Mean & $\begin{array}{c}\text { Mean } \\
(\%)\end{array}$ & $\begin{array}{l}\text { STD } \\
\text { DEV }\end{array}$ \\
\hline $\begin{array}{l}\text { Legal environment is an impediment to } \\
\text { financial system development. }\end{array}$ & 3 & 33.3 & 39.4 & 18.2 & 6.1 & 2.9 & 58.2 & 0.9475 \\
\hline $\begin{array}{c}\text { A favourable legal environment } \\
\text { facilitates stock market development }\end{array}$ & 0 & 5.9 & 5.9 & 61.8 & 26.5 & 4.1 & 81.8 & 0.7535 \\
\hline $\begin{array}{c}\text { There are law and enforcement } \\
\text { mechanisms that protect investors at } \\
\text { the NSE }\end{array}$ & 0 & 0 & 5.9 & 50 & 44.1 & 4.4 & 87.6 & 0.6038 \\
\hline $\begin{array}{l}\text { There are regulations that protect } \\
\text { creditors and minority investors at the } \\
\text { NSE }\end{array}$ & 2.9 & 8.8 & 8.8 & 47.1 & 32.4 & 4.0 & 79.4 & 1.0294 \\
\hline $\begin{array}{l}\text { Laws and regulations at the NSE are } \\
\text { prohibitive in nature }\end{array}$ & 5.9 & 35.3 & 35.3 & 17.6 & 5.9 & 2.8 & 56.5 & 0.9991 \\
\hline $\begin{array}{l}\text { Regulatory bodies enact policies that } \\
\text { affect the development of the stock } \\
\text { Market. }\end{array}$ & 2.9 & 5.9 & 20.6 & 50 & 20.6 & 3.8 & 75.9 & 0.9464 \\
\hline $\begin{array}{l}\text { Regulatory authorities for the NSE use } \\
\text { a heavy-handed type of control }\end{array}$ & 5.9 & 23.5 & 38.2 & 29.4 & 2.9 & 3.0 & 60.0 & 0.9535 \\
\hline $\begin{array}{l}\text { Proactive, creative and supportive } \\
\text { regulations assist in the creation of a } \\
\text { more vibrant and forward looking } \\
\text { capital market environment. }\end{array}$ & 0 & 5.9 & 17.6 & 23.5 & 52.9 & 4.2 & 84.7 & 0.9553 \\
\hline $\begin{array}{c}\text { CMA is a catalyst in development } \\
\text { rather than a traditional regulator of } \\
\text { NSE }\end{array}$ & 0 & 5.9 & 20.6 & 41.2 & 32.4 & 4.0 & 80.0 & 0.8876 \\
\hline & & & & & & 3.7 & 73.8 & 0.9 \\
\hline
\end{tabular}

\section{Market Capitalization Ratio}

The dependable variable of interest was Nairobi securities exchange development which was measured using market capitalization as a proportion of GDP. This measure equals the value of listed shares divided by GDP. The assumption behind this measure is that the overall market size is positively correlated with the ability to mobilize capital and diversify risk on an economy wide basis. Market capitalization (also known as market value) is the share price times the number of shares outstanding (including their several classes) for listed domestic companies, was the dependent variable of the study. The table below shows the market capitalization ratio for 2006 to 2015 with descriptive statistics; 
Table 9: Market Capitalization Ratio

\begin{tabular}{|c|r|r|r|}
\hline Year & $\begin{array}{c}\text { Stock Market } \\
\text { capitalization } \\
\text { (KShs Bns) }\end{array}$ & $\begin{array}{c}\text { GDP (kshs } \\
\text { Bns) }\end{array}$ & $\begin{array}{r}\text { Stock Market } \\
\text { Capitalization, } \\
\text { Percentage of GDP }\end{array}$ \\
\hline 2006 & 791.58 & $1,622.57$ & $48.79 \%$ \\
\hline 2007 & 851.13 & $1,833.51$ & $46.42 \%$ \\
\hline 2008 & 853.88 & $2,111.17$ & $40.45 \%$ \\
\hline 2010 & 834.17 & $2,365.45$ & $35.26 \%$ \\
\hline 2011 & $1,166.99$ & $2,553.73$ & $45.70 \%$ \\
\hline 2012 & 868.24 & $3,048.87$ & $28.48 \%$ \\
\hline 2013 & $1,272.00$ & $4,261.37$ & $40.85 \%$ \\
\hline 2014 & $1,920.72$ & $4,745.14$ & $42.57 \%$ \\
\hline & $2,300.05$ & $5,402.41$ & $32.74 \%$ \\
\hline Mean & $2,049.54$ & $6,260.65$ & $39.07 \%$ \\
\hline Standard Deviation & $1,290.83$ & $3,420.49$ & $6.78 \%$ \\
\hline
\end{tabular}

The above table shows that the Nairobi securities exchange has been performing well some years and other years dismally. One of the contributing factors for its performance are the independent variables for this study which were market information, market efficiency, market transparency, market openness, transaction processing system and operating processing cost and legal and regulatory framework. From the data collected, the highest market capitalization ratio was in 2006 at $48.79 \%$ with the lowest being in 2011 at $28.48 \%$. The mean was $39.07 \%$ indicating that themarket has been having an average performance; with a low standard deviation at $6.78 \%$, the range of performance hasn't been fluctuating a lot. The figure below shows a graphical representation of Kenya's monthly Capitalization levels for the period under study;

\section{Correlation Analysis}

The table below displays the value of the correlation coefficient and the significance value for each pair of variables used in the Paired Samples T Test procedure. 
Table 10: Correlation Analysis

\begin{tabular}{|c|c|c|c|c|c|c|c|}
\hline & & $\begin{array}{l}\text { Market } \\
\text { Informat } \\
\text { ion }\end{array}$ & $\begin{array}{l}\text { Market } \\
\text { Efficie } \\
\text { ncy }\end{array}$ & $\begin{array}{l}\text { Market } \\
\text { Transpare } \\
\text { ncy }\end{array}$ & $\begin{array}{l}\text { Market } \\
\text { Openn } \\
\text { ess }\end{array}$ & $\begin{array}{l}\text { TPS and } \\
\text { Operatin } \\
\text { g/ } \\
\text { Transact } \\
\text { ion Cost }\end{array}$ & $\begin{array}{l}\text { Legal } \\
\text { and } \\
\text { Regulat } \\
\text { ory } \\
\text { Framew } \\
\text { ork }\end{array}$ \\
\hline $\begin{array}{l}\text { Market } \\
\text { Informati } \\
\text { on }\end{array}$ & $\begin{array}{l}\text { Pearson } \\
\text { Correlat } \\
\text { ion } \\
\text { Sig (2 } \\
\text { tailed) } \\
\mathrm{N}\end{array}$ & 34 & $\begin{array}{r}0.239 * \\
* \\
0.001 \\
34\end{array}$ & $\begin{array}{r}0.0389 * * \\
0.002 \\
34\end{array}$ & $\begin{array}{r}0.429 * \\
* \\
0.001 \\
34\end{array}$ & $\begin{array}{r}0.136 * * \\
0.049 \\
34\end{array}$ & $\begin{array}{r}0.528 * * \\
0.045 \\
34\end{array}$ \\
\hline $\begin{array}{c}\text { Market } \\
\text { Efficienc } \\
\text { y }\end{array}$ & $\begin{array}{c}\text { Pearson } \\
\text { Correlat } \\
\text { ion } \\
\text { Sig (2 } \\
\text { tailed) } \\
\mathrm{N} \\
\end{array}$ & $\begin{array}{r}0.239 * * \\
0.001 \\
34 \\
\end{array}$ & $\begin{array}{r}- \\
34 \\
\end{array}$ & $\begin{array}{r}0.495 * * \\
0.001 \\
34 \\
\end{array}$ & $\begin{array}{r}0.370 * \\
* \\
0 \\
34 \\
\end{array}$ & $\begin{array}{r}0.815^{* *} * \\
0.021 \\
34 \\
\end{array}$ & $\begin{array}{r}0.612 * * \\
0.002 \\
34 \\
\end{array}$ \\
\hline $\begin{array}{c}\text { Market } \\
\text { Transpare } \\
\text { ncy }\end{array}$ & $\begin{array}{c}\text { Pearson } \\
\text { Correlat } \\
\text { ion } \\
\text { Sig }(2 \\
\text { tailed) } \\
\mathrm{N} \\
\end{array}$ & $\begin{array}{r}0.0389 * \\
* \\
0.002 \\
34 \\
\end{array}$ & $\begin{array}{r}0.495 * \\
* \\
0.001 \\
34 \\
\end{array}$ & $\begin{array}{r}- \\
34\end{array}$ & $\begin{array}{r}0.648^{*} \\
* \\
0.002 \\
34 \\
\end{array}$ & $\begin{array}{r}0.635^{* * *} \\
0.001 \\
34 \\
\end{array}$ & $\begin{array}{r}0.095 * * \\
0.0341 \\
34 \\
\end{array}$ \\
\hline $\begin{array}{l}\text { Market } \\
\text { Openness }\end{array}$ & $\begin{array}{l}\text { Pearson } \\
\text { Correlat } \\
\text { ion } \\
\text { Sig }(2 \\
\text { tailed) } \\
\text { N }\end{array}$ & $\begin{array}{r}0.429 * * \\
0.001 \\
34\end{array}$ & $\begin{array}{r}0.370 * \\
* \\
0 \\
34\end{array}$ & $\begin{array}{r}0.648 * * \\
0.002 \\
34\end{array}$ & 34 & $\begin{array}{r}0.348 * * \\
0.002 \\
34\end{array}$ & $\begin{array}{r}0.536 * * \\
0.001 \\
34\end{array}$ \\
\hline $\begin{array}{l}\text { TPS and } \\
\text { Operating } \\
\text { / } \\
\text { Transacti } \\
\text { on Cost }\end{array}$ & $\begin{array}{l}\text { Pearson } \\
\text { Correlat } \\
\text { ion } \\
\text { Sig }(2 \\
\text { tailed) } \\
\text { N }\end{array}$ & $\begin{array}{r}0.049 \\
34\end{array}$ & $\begin{array}{r}0.815^{*} \\
*\end{array}$ & $\begin{array}{r}0.001 \\
34\end{array}$ & $\begin{array}{r}0.348 * \\
* \\
0.002 \\
34\end{array}$ & 34 & $\begin{array}{r}0.476 * * \\
0 \\
34\end{array}$ \\
\hline $\begin{array}{l}\text { Legal and } \\
\text { Regulator } \\
\mathrm{y} \\
\text { Framewor } \\
\mathrm{k}\end{array}$ & $\begin{array}{l}\text { Pearson } \\
\text { Correlat } \\
\text { ion } \\
\text { Sig }(2 \\
\text { tailed) } \\
\mathrm{N}\end{array}$ & $\begin{array}{r}0.045 \\
34\end{array}$ & $\begin{array}{r}0.612 * \\
*\end{array}$ & $\begin{array}{r}0.0341 \\
34\end{array}$ & $\begin{array}{r}0.536 * \\
*\end{array}$ & $0.476 * *$ & 34 \\
\hline
\end{tabular}

**Correlation is significant at the 0.05 level (2-tailed).

The results suggest a strong correlation between TPS and operating/ Transaction cost and market efficiency with a rho of 0.815 and a $p$ value of 0.021 . The results also suggest that the relationship between market information and legal and regulatory framework ( $r h o=0528, p=0.045)$ is 
statistically significant. Legal and regulatory framework and TPS and Operating/Transaction cost had a Rho of 0.476 and a $p$ value of 0.000 therefore denoting statistical significance. Similarly, the legal and regulatory framework and market efficiency posted a rho of 0.612 with a $p$ value of 0.000 therefore providing a statistical significance. Market transparency and TPS operating/ transaction cost had a rho of $0.635, \mathrm{p}=0.001$ further pointing to a statistical significance. On the same note, the market efficiency and market transparency correlated at $\mathrm{rho}=0.495$ and $\mathrm{p}=0.001$; This therefore is statistically significant. Market information and market efficiency had a Rho of 0.239 and a $p$ value of 0.001 , market information and market transparency had a Rho of 0.0389 and a $\mathrm{p}$ value of 0.002. Market openness and market efficiency correlated at Rho $=0.370$ and $p=0.000$ implying statistical significance. Finally, the legal and regulatory framework market transparency were at a correlation of rho $=0.095$ and $\mathrm{p}=0.0341$ revealing statistical significance.

Thus generally, the above table shows that there is a very positive correlation between legal and regulatory framework, market efficiency, market transparency, TPS operating/transaction cost market openness and market information at $95 \%$ which are statistically significant at confidence level.

\section{Multiple Regression Analysis}

A multiple regression analysis was conducted to find out the effect of market information, market efficiency, market openness, market transparency, transaction processing system and transaction/operating cost and legal and regulatory framework on the development of NSE as a proxy for market infrastructure factors. Model summary table below shows the coefficient of determination $\left(\mathrm{R}^{2}\right)$ which explains the percentage of the variation in the development of NSE

Table 11: Model Summary

\begin{tabular}{lllll}
\hline Model & $\mathrm{R}$ & $\mathrm{R}$ square & AdjustedR square & Standard Error \\
\hline & & & & \\
1 & $0.8955^{\mathrm{b}}$ & 0.8911 & 0.64306 & 0.4452 \\
\hline
\end{tabular}

b. Dependent variable: Development of the NSE

From the results of the table above, the regression model containing market information, market efficiency, market transparency, market openness, transaction processing system and operating/transaction cost and legal and regulatory framework as the predictor variables explains $89.11 \%$ of the variation in development of the NSE while the remainder (10.99\%) can be explained by other factors not included in this model.

Adjusted R squared is coefficient of determination which tell us the variation in the dependent variable due to changes in the independent variable, from the findings in the above table the value of adjusted $\mathrm{R}$ squared was 
0.64306 an indication that there was variation of $64.306 \%$ on development of the NSE due to changes in the independent variables which are market information, market efficiency, market transparency, market openness, transaction processing system and operating/transaction cost and legal and regulatory framework at $95 \%$ confidence interval. This shows that $64.306 \%$ of development in the NSE could be attributed to market information, market efficiency, market transparency, market openness, transaction processing system and operating/transaction cost and legal and regulatory framework.

Table 12: ANOVA

\begin{tabular}{llllll}
\hline & $d s$ & $S S$ & $M S$ & $F$ & Significance F \\
\hline Regression & 6 & 9963.12 & 1660.52 & 56.0036 & $0.017^{\text {a }}$ \\
Residual & 3 & 88.9507 & 29.6502 & & \\
Total & 9 & 10052.1 & & \\
\hline \multicolumn{5}{c}{ a. } & Predictors (Constant), Market information, \\
b. Dependent variable: Development of the NSE & \\
\hline
\end{tabular}

From the above table, the significance value is 0.017 which is less than 0.05 thus the model is statistically significant in predicting how market information, market efficiency, market transparency, market openness, transaction processing system and operating/transaction cost and legal and regulatory framework influences development of the Nairobi Securities Exchange. An F statistic of 56.004 with a p value less than the conventional $5 \%$ indicates that the overall model was significant at $95 \%$ confidence level.

Table of coefficients below presents the unstandardized and standardized coefficients of the model, the t-statistic for each coefficient and the associated $\mathrm{p}$-values. The predictor variables had significant positive relationship with development of the NSE.

Table 13: Coefficients

\begin{tabular}{|c|c|c|c|c|c|}
\hline & \multicolumn{2}{|c|}{$\begin{array}{l}\text { Unstandardized } \\
\text { Coefficients }\end{array}$} & \multicolumn{2}{|c|}{$\begin{array}{c}\text { Standardized } \\
\text { Coefficients }\end{array}$} & \multirow[b]{2}{*}{$P$-value } \\
\hline & $B$ & $\begin{array}{c}\text { Std } \\
\text { Error }\end{array}$ & Beta & $t$ Stat & \\
\hline 1 (constant) & 0.252 & 0.013 & & 0 & 0 \\
\hline Market information & 0.382 & 0.1645 & 0.264 & 1.02097 & 0.03824 \\
\hline Market efficiency & 0.0966 & 0.1448 & 0.0751 & 0.1148 & 0.01159 \\
\hline Market transparency & 0.3483 & 0.1326 & 0.3129 & 2.0986 & 0.01267 \\
\hline Market openness, & 0.3684 & 0.1241 & 0.3287 & 0.5517 & 0.00619 \\
\hline TPS and Operating/transaction cost & 0.5074 & 0.1949 & 0.4765 & 0.5512 & 0.00199 \\
\hline Legal and regulatory framework & 0.2266 & 0.1187 & 0.1908 & 1.4029 & 0.02552 \\
\hline
\end{tabular}

The first hypothesis Ho1-Market information does not significantly affect the development of Nairobi Securities Exchange. This null hypothesis was tested at 5\% significant level and rejected since the p-value was less than 
$5 \%$ with $\mathrm{t}=1.02097$. This implies that market information does significantly affect NSE development. The results are similar to Osei (1998) who analysed the factors affecting the development of an emerging capital market with a specific focus on the Ghana stock market with a focus on institutional factors. The study found that the most significant factors impinging on the development of the Ghana stock market is lack of national awareness and lack of knowledge about stock markets

The second null hypothesis Ho2-Market efficiency does not significantly affect the development of Nairobi Securities Exchange was tested at 5\% significant level and rejected at since the p-value was less than $5 \%$ with $\mathrm{t}=0.1148$. This implies that market efficiency does significantly affect NSE development. According to Demirguc-Kant and Levine (1996), they observed that economies with strong information and unrestricted international capital flow tend have more liquid markets.

The third null hypothesis Ho3-Market transparency does not significantly affect the development of Nairobi Securities Exchange was tested at 5\% significant level and rejected at 5\% since the p-value was less than 5\% with $\mathrm{t}=2.0986$. This implies that market transparency does significantly affect the development of NSE. These results are in line with Sejjaaka (2011) in challenges to the growth of capital markets in underdeveloped economies, the case for Uganda, who concluded that there is a need to improve levels of disclosure by firms because these firms occupy an important place in the business space. As firms' disclosure improves, so will their readiness to go IPO and firms need to legitimize their business so as to increase their acceptability as investment vehicles for mobilising private savings.

The fourth hypothesis Ho4-Market openness does not significantly affect the development of Nairobi Securities Exchange. This null hypothesis was tested at 5\% significant level and rejected since the p-value was less than $5 \%$ with $\mathrm{t}=0.5517$. This implies that market openness does significantly affect development of NSE. Similarly,Bruner et al (2003) in the study on investing in emerging markets to ascertain the extend of market openness in those countries. Using regression analysis, they found that the level of openness contributes to stock market development

The fifth hypothesis Ho5- Transaction processing system and operating/ transaction cost does not significantly affect the development of Nairobi Securities Exchange. The null hypothesis was tested at 5\% significant level and rejected at 5\% since the p-value was less than 5\% with $\mathrm{t}=0.5512$. This implies that transaction processing system and cost does significantly affect NSE development.These results are in line with Osei (1998) who found out that transaction costs are a hindrance to stock market development. 
The sixth hypothesis Ho6-Legal and regulatory framework does not significantly affect the development of Nairobi Securities Exchange. This null hypothesis was also tested at 5\% significant level and rejected at 5\% since the $\mathrm{p}$-value was less than $5 \%$ with $\mathrm{t}=1.4029$. this implies that the legal and regulatory framework does significantly affect NSE development. The results are in line with the study done by Pagano (1993) in financial markets and growth, which shows that regulatory and institutional factors may influence the efficient functioning of stock markets. For example, mandatory disclosure of reliable information and regulations that instil investor's confidence. Yartey and Adjasi (2007) in their study on macroeconomic and institutional determinants of stock market development in Africa found that a percentage point increase in the quality of legal and political institutions tends to increase stock market development in Africa.

The findings confirm that there is a statistically significant influence of Market information, Market efficiency, Market transparency, Market openness, Transaction processing system and Operating/transaction cost and Legal and regulatory framework on the development of the NSE. This implies that a unit increase in the predictor variables leads to a significant increase on the development of the NSE as demonstrated in the equation below: $0.226 \mathrm{X}_{6}$

$$
\mathrm{Y}=0.252+0.382 \mathrm{X}_{1}+0.097 \mathrm{X}_{2}+0.348 \mathrm{X}_{3}+0.368 \mathrm{X}_{4}+0.507 \mathrm{X}_{5}+
$$

From the significance column of the provided table, at $5 \%$ level of significance, it was observed that Market information, Market efficiency, Market transparency, Market openness, Transaction processing system and Operating/transaction cost and Legal and regulatory framework are the main variables that explain the development of the NSE. From the above regression equation, a unit increase in market information leads to a 0.382 increase in NSE development, a unit increase in Market efficiency leads to a 0.097 increase in NSE development, a unit increase in Market transparency leads to a 0.348 increase in NSE development, a unit increase in Market openness leads to a 0.368 increase in NSE development, a unit increase in Transaction processing system and Operating/transaction cost leads to a 0.507 increase in NSE development and a unit increase in Legal and regulatory framework leads to a 0.226 increase in NSE development.

\section{Conclusion}

The result of the study indicated that market information affects the development of Nairobi Securities Exchange by 76\%. Respondents agreed that since there are still some barriers to dissemination of information, unsuspecting investors can be harmed by those with access to information not available to the public at large and that the managers of a firm and financial market professionals know more about that firm's market prospects and 
investment opportunities than do outsiders as they often have access to information that is not widely available therefore disclosure will facilitate increased investors' confidence in the stock markets. Due to this listed companies trading in NSE should be subjected to additional disclosure requirements imposed as listing rules.

The result of the study indicated that market efficiency affects the development of Nairobi Securities Exchange by $67.8 \%$. According to the study there are some information asymmetries, under-pricing of securities and prices of securities listed at the NSE do not reflect all available information and thus public disclosure of relevant information about securities is important for pricing efficiency and market confidence

The result of the study indicated that market transparency affects the development of Nairobi Securities Exchange by $75.9 \%$. This implies that some transactions are not made known to the public as some trading is conducted privately outside the NSE. Emerging markets are likely to be less transparent than developed market and the degree of market transparency affects investors' ability to gain information and develop performance expectations since transparency in dealings enhance the market confidence.

Another objective for this study was to find out the effect of market openness on the development of the NSE. The result of the study indicated that market openness affects the development of Nairobi Securities Exchange by $59.6 \%$. According to the study, NSE is not open to all investors whether local or foreign and in addition there are restrictions on foreign ownership. Excessive barriers to foreign investors including the Kenyan 25\% rule hamper the development of NSE.

Transaction processing system as well as transaction cost affects the development of Nairobi Securities Exchange by 68.6\%. Therefore the clearance and settlement system used at the NSE is fast and effective with a good number of transactions being processed on time and this led to increased turnover at the NSE. The processing system guarantee that the prices obtained by buyers and sellers are good. Investors' usually aim at minimizing cost to increase their returns and thus unreasonably high costs of transactions affect market development.

It's clear from the study that legal and regulatory environment plays an important role in the development of the securities markets and affects the development of the NSE by $73.8 \%$. Favourable legal environment facilitates stock market development hence the law and enforcement mechanisms that protect creditors and minority investors in the NSE should be put in place, as lack of this could be an impediment to the NSE. Proactive, creative and supportive regulations assist in the creation of a more vibrant and forward looking capital market environment. 
The study recommends that NSE needs to be developed further to enhance domestic resource mobilization. Various policies and programs that affect stock market development such as regulation of institutional investor and privatization need to be addressed immediately. The policymakers should consider reducing impediments to stock market development by easing restrictions on international capital flows. NSE should play an increasingly educational role and CMA should also change its approach from heavy handed type to more productive, they should see themselves as catalyst in the stock market development

\section{References:}

1. .Aduda et.al (2012). The Determinants of Stock Market Development: The Case for the Nairobi Stock Exchange. International Journal of Humanities and Social Science, 2(9).

2. Bencivenga, Valerie R., Bruce D. Smith, and Ross M. Starr. (1995). Equity Markets, Transactions Costs, and Capital Accumulation: An Illustration. The World Bank Economic Review 10 (2).

3. Bruner R et al (2003).Investing in Emerging Markets. Charlott Ville Virginia. The Research Foundation of AIMR 2003.Capital Market Authority Website: www.cma.or.ke

4. Chepkoiwo N.K. (2011) Factors affecting the development of emerging capital markets, the case of Nairobi stock Exchange.University of Nairobi.

5. Demirguc-Kunt, Asli, and Ross Levine. (1996). Stock Market Development and Financial Intermediaries: Stylized Facts," The World Bank Economic Review 10 (2).

6. Levine, R. (1990). Stock Market Growth, and Policy, Research, and external Affairs, Working Papers Macroeconomic Adjustment and Growth-The World Bank-WPS,484 London.

7. Mbaru .J.(2003) Transforming African new pathways to development ,East African Educational publishers. Nairobi

8. Muyundo, M. and Kibua, T. (2004). Capital market policies in Kenya; Historical Trends and challenges. IPAR Discussion paper 04812004, Nairobi

9. Osei, K (1998).Analysis of factors affecting the Development of an emerging capital Market:The case of the Ghana Stock Market.

AERC Research Paper 76. African Economic Research Consortium, Nairobi.

10. Sejjaaka S. (2011).Challenges to the Growth of Capital Markets in Underdeveloped Economies: The Case for Uganda, Investment Climate and Business Environment Research Fund ICBE-RF Report No 02/11 
11. Seyyed Ali PaytakhtiOskooe (2010): Emerging Stock Market Performance and Economic Growth." American Journal of Applied Science 7(2): 265-269, 2010

12. The Capital Markets Authority Act, 2002 (August 2000)

13. The Central Depositories Act 2000 (August 2000)

14. Wagacha, M (2001).Kenya's Capital Market: To list or not to list-A survey of Enterprise Attitudes. IPAR Discussion Paper 28

15. Yartey and Adjasi (2007).Macroeconomic and Institutional Determinants of Stock Market Development in Africa. Management and Economic Development in Sub-Saharan Africa: Theoretical and Applied Perspective. London: Adonis and Abbey Publishers. 